\title{
A meta-analysis of c-Met expression in head and neck cancer
}

\author{
Lei Li ${ }^{1, *}$, Haiming Sun ${ }^{2, *}$, Zhijun Sun ${ }^{3, *}$, Xin Huang ${ }^{1}$, Xiao Li ${ }^{4}$, Lihua Sun ${ }^{5}$, Lei Zhang ${ }^{1}$, \\ Xiaodan Zhang ${ }^{1}$, Longwei $\mathrm{Ye}^{1}$, Jie Yuan ${ }^{1}$, Limin Mao ${ }^{6}$ and Guolin $\mathbf{L i}^{6}$ \\ ${ }^{1}$ Department of Preventive Dentistry, The First Affiliated Hospital of Harbin Medical University, Harbin, 150001, China \\ ${ }^{2}$ Laboratory of Medical Genetics, Harbin Medical University, Harbin, 150081, China \\ ${ }^{3}$ Department of Public Health, People's Hospital of Rongcheng, Rongcheng, 264300, China \\ ${ }^{4}$ Department of Oral and Maxillofacial Surgery, The First Affiliated Hospital of Harbin Medical University, Harbin, 150001, China \\ ${ }^{5}$ Department of Dentistry, The Electric Power Hospital of Heilongjiang Province, Harbin, 150030, China \\ ${ }^{6}$ Department of Oral and Maxillofacial Surgery, The First Affiliated Hospital of Harbin Medical University, Harbin, 150001, China \\ *These authors contributed equally to this work
}

Correspondence to: Limin Mao, email: hao621126@126.com

Guolin Li, email: liguolin@126.com

Keywords: c-Met; head and neck cancer; meta-analysis; prognosis

Received: August 09, $2017 \quad$ Accepted: October 29, 2017

Published: December 23, 2017

Copyright: $\mathrm{Li}$ et al. This is an open-access article distributed under the terms of the Creative Commons Attribution License 3.0 (CC BY 3.0 ), which permits unrestricted use, distribution, and reproduction in any medium, provided the original author and source are credited.

\section{ABSTRACT}

The prognostic role of c-Met expression in head and neck cancer patients were controversial among different studies. Thus, we performed a meta-analysis to evaluate the relationships between c-Met expression and survival and clinical parameters of head and neck cancer patients. The databases PubMed and Embase were searched. Summary hazard ratio (HR) and $95 \%$ confidence intervals (CIs) were calculated to analyze the correlations between c-Met expression and overall survival (OS), and disease-free survival (DFS). Furthermore odds ratios (ORs) and 95\% CIs were used to describe the relationships between c-Met expression and different clinicophathological parameters. A total of 2,417 patients from 19 studies were enrolled in the final analysis. The results showed that C-Met expression was significantly associated with OS (HR: 1.65; 95\% CI: 1.20-2.27, $P=0.002$ ) while not DFS (HR: 1.48, 95\% CI: 0.99-2.20, $P=0.055$ ). And C-Met expression was associated with the $\mathbf{N}$ stage of head and neck cancer patients (OR: 2.11; 95\% CI: 1.12-3.96, $P=0.02$ ). These results suggested that c-Met expression was a risk factor for head and neck cancer; increased c-Met expression could be a predictor of a poorer prognosis for the patients.

\section{INTRODUCTION}

Head and neck cancer (HNC) are cancers that arise in the tissues of the head and neck, which includes cancers occurred in oral cavity, pharynx and larynx. Worldwide, approximately 550,000 individuals develop head and neck cancer and about 380,000 die from this disease every year [1]. In the United States, there would be more than 63,000 new cases of HNC and 13,000 deaths in 2017 [2]. Despite the incidence and mortality rate of head and neck cancer declined in the past two decades, there were no standard or routine screening tests for head and neck cancers. It is necessary to find new biomarkers that could help to screen high-risk individuals and predict the prognosis of the patients.
c-Met is a member of receptor tyrosine kinase family, it also known as hepatocyte growth factor receptor (MET). It is overexpressed in multiple human cancers, activation of c-Met could mediate the migration, invasion, and angiogenesis of tumor cells [3]. By immunohistochemistry, Knowles et al found that c-Met and /or its ligand (hepatocyte growth factor, HGF) overexpressed in nearly $80 \%$ of primary HNC tumors [4]. The prognostic role of overexpression of c-Met had been investigated in head and neck cancer [5-7], but the results were inconsistent among different studies. Thus, we carried out a system review to evaluate the prognostic role of overexpression of c-Met in head and neck cancer patients. 


\section{MATERIALS AND METHODS}

\section{Literature searching}

A comprehensive literature retrieve was carried out in PubMed and Embase for the eligible studies published up to June 2017. The following keywords were used in the literature searching: "c-Met" and "head and neck cancer" or "oral cancer" or "pharyngeal cancer" or "laryngeal cancer" or "nasopharyngeal cancer" and "prognosis" or "survival". Furthermore, we manually searched the reference lists of relevant articles to identify the possible missing publications. Studies were included unless they met the following inclusion criteria: provided survival data in head and neck cancer patients stratified by c-Met expression and sufficient data to calculate an estimate of hazard ratio (HR) and a 95\% confidence interval (CI); the expression of c-Met was measured in the head and neck cancer specimens; and all selected patients were pathologically confirmed. All publications were reviewed to avoid the duplicate data. If there were overlapping between studies, only the most recent or most complete data was included.

\section{Data extraction and quality assessment}

Five investigators were divided into two groups and they conducted the literature review and extracted data from each included publication separately. For each article, the following information was extracted: author's name, publication year, sample size, research country, tumor types, clinicopathological data (number of patients with different gender, $\mathrm{T}$ stage, $\mathrm{N}$ stage and clinical stage), c-Met expression detection methods, cut-off level of high expression, and survival data (HR and its $95 \%$ CIs for OS and DFS). If the survival data were not reported in the publications, we extracted it from the Kaplan-Meier curves by the methods of Jayne et al. [8]. The extracted data were crosschecked and any disagreements were resolved by discussion.

\section{Statistical analysis}

Overall survival (OS) and disease free survival (DFS) were the main outcomes to evaluate the prognostic value of c-Met expression, hazard ratios (HRs) and 95\% confidence intervals (CIs) were used to combine as the effective value. For clinicopathological data, odds ratios (ORs) and 95\% CIs were used to describe the relationships between c-Met expression and different clinicophathological parameters. Pooled HRs or ORs with $95 \%$ CIs were calculated using random-effects model due to the potential substantial heterogeneity among studies [9]. $\mathrm{I}^{2}$ statistic was used to detect the heterogeneity, it indicated the presence of significant heterogeneity if $\mathrm{I}^{2} \geq 50 \%$ [10]. For survival datasets, we further investigated potential heterogeneity by subgroup analyses stratified by tumor types, region of the study, and calculation methods of HR. We used sensitivity analysis to assess the stability of the results. Potential publication bias was evaluated by the shape of funnel plots, an asymmetric plot indicates a possible publication bias [11]. The publication bias was further assessed by Egger's test, $P<0.05$ was considered indicative of significant publication bias [12]. The "trim and fill" method was used to examine the potential impact of the publication bias on the interpretation of the data if publication bias was found [11]. All statistical analyses were performed by Stata statistical software (version 11.0; Stata Corporation, College Station, TX, USA).

\section{RESULTS}

\section{Literature searching and study characteristics}

A total of 348 publications were found by the databases searching. After title and abstract checking, 36 studies remained for the further evaluating in details, in which 15 articles were excluded for there were no enough data to calculate the survival rate [13-27], one article was removed because of duplication [28]. So, a total of 20 publications were fulfilled the eligibility criteria [5-7, 29-45]. Among them, one study was excluded by the poor data quality [45], so 19 publications were included in the final analysis. The details of the procedures of literature screening were shown in Figure 1. Among the 19 studies, 5 studies reported head and neck cancer without site information [7, 33, 36, 39, 43], 4 studies focused on oral and oropharyngeal cancer [30, 32, 40, 44], 3 for tongue cancer [6, 29, 34], 3 for nasopharyngeal cancer [5, 35, 42], 2 for salivary gland cancer [37, 38], 1 for hypopharyngeal cancer [41] and another one for tonsillar cancer [31]. The total number of patients included in the meta-analysis was 2,417, the mean sample size was 127 (ranges from 33 to 396). Among them, 16 studies reported the overall survival (OS) and 8 for disease-free survival (DFS). We extracted hazard ratio (HR) and a 95\% confidence interval (CI) from the Kaplan-Meier curves in 8 articles. The main characteristics of the included studies were listed in Table 1.

\section{c-Met expression and the survival of head and neck cancer}

We used OS and DFS as the main outcomes to evaluate the impact of c-Met expression on the survival of head and neck cancer patients. In the collected dataset, there were 16 studies reported overall survival (OS) and 8 studies reported disease-free survival (DFS). Firstly, we analyzed the relationships between c-Met expression and OS in 16 studies. The results showed that the patients with higher c-Met expression had a poor prognosis than those 
with lower expression (HR: 1.65; 95\% CI: 1.20-2.27, $P=0.002$ ). Subgroup analysis was carried out based on tumor types, regions of the study and calculation methods of HR. Based on the region of study, we found significant association between c-Met expression and survival rate in Asian studies. In the subgroup analysis by statistical methodology, there was significant difference in the group of multivariable analysis. For different tumor types, we found c-Met expression was significant associated with the survival rate of HNC and NPC (Figure 2).

Then HR and 95\% CI were calculated to test the relationship between c-Met expression and disease-free survival (DFS). The results revealed that there was no significant association between c-Met expression and DFS rate (HR: 1.48 ; 95\% CI: $0.99-2.20, P=0.055$ ). In the subgroup analysis, the significant association was just found in "Asia" and "Multivariate" (Figure 3). All the details were listed in Table 2.

To evaluate the reliability of the results, sensitivity analysis was carried out by deleted single study each time. There was no significant change on the results of OS by removing any of the studies. As for DFS, the association changed into significant when we delete the study of "Lo Muzio", Figure 4. The results shown single study basically did not have any influence on the results. Begg's funnel plots were constructed to evaluate the publication bias; we did find the sign of publication bias by the shapes of the plots in OS while not in DFS (Figure 5). The results of Egger's test were consistent with the plot $(P=0.006$ for OS; $P=0.335$ for DFS). The "trim and fill" method was used to adjust for the publication bias and to find the possible influence of the bias on the results. By this method, we estimated there would be one missing study, the filled dataset is much more symmetric than the original data (Figure 6). Compared with the original results (HR: 1.65; 95\% CI: $1.20-2.27, P=0.002)$, the association between c-Met expression and the prognosis did not change when the missing study were added (HR: 1.56; 95\% CI: 1.16-2.89, $P=0.004)$.

\section{c-Met expression and clinical parameters}

ORs and 95\% CI were calculated to evaluate the associations between c-Met expression and different clinical parameters such as gender (male vs. female), T stage (T1/ T2 vs. T3/T4), $\mathrm{N}$ stage (N0 vs. $\mathrm{N}+$ ) and clinical stage (I/II vs. III/IV). Pooled ORs showed that c-Met expression was association with gender, $\mathrm{T}$ stage, $\mathrm{N}$ stage and clinical stage. But the association was not significant except between c-Met expression and N stage (OR: 2.11; 95\% CI: 1.12-3.96, $P=0.02$ ). Sensitivity analysis and publication bias were carried out too. The results did not change after we deleted any single study (data not show). No publication bias was found in all of these analyses. The details were showed in Table 3.

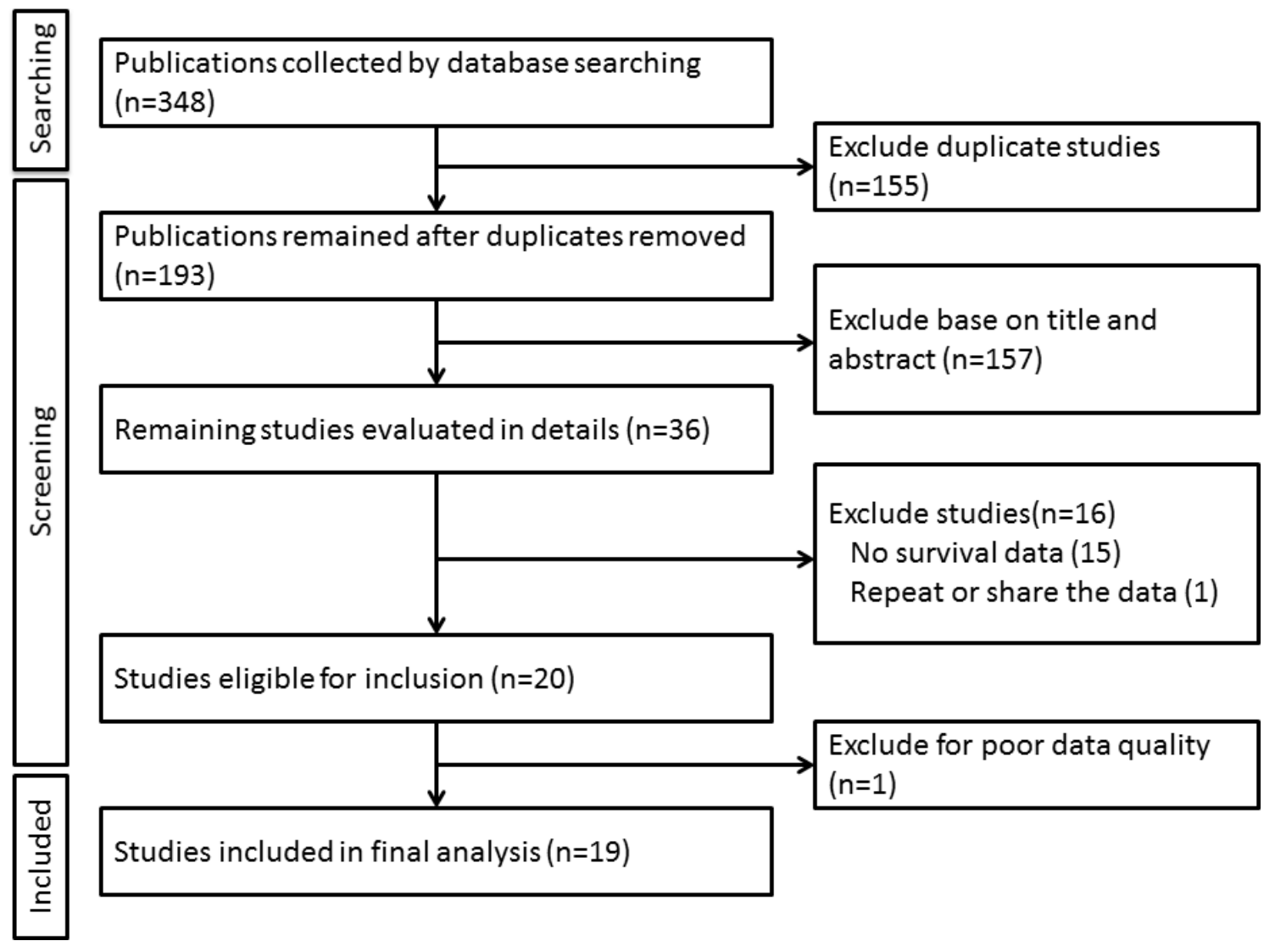

Figure 1: Flow chart of the literature searching. 
Table 1: Main characteristics of the studies included in this meta-analysis

\begin{tabular}{|c|c|c|c|c|c|c|c|c|c|}
\hline Study ID & $\begin{array}{l}\text { Publication } \\
\text { date }\end{array}$ & Country & $\begin{array}{l}\text { Sample } \\
\text { size }\end{array}$ & $\begin{array}{c}\text { Median or } \\
\text { mean age/ } \\
\text { range(year) }\end{array}$ & $\begin{array}{l}\text { Tumor } \\
\text { type }\end{array}$ & $\begin{array}{l}\text { Follow-up } \\
\text { time/months }\end{array}$ & Cut-off & $\begin{array}{l}\text { Outcome } \\
\text { (OS/DFS) }\end{array}$ & $\begin{array}{l}\text { Source } \\
\text { of HR }\end{array}$ \\
\hline Kwon & 2014 & South Korea & 79 & NA & $\mathrm{HNC}$ & NA & $\begin{array}{l}\text { Staining intensity } \\
\text { and the proportion of } \\
\text { positively stained cells } \\
\text { were summed up and } \\
\text { the scores } \geq 4\end{array}$ & OS/DFS & I \\
\hline Baschnagel & 2014 & U.S.A & 107 & 62 & $\mathrm{HNC}$ & $35(1-93)$ & $\begin{array}{l}\text { Staining intensity value } \\
\text { of } 2.5 \text { or higher }\end{array}$ & OS/DFS & $\mathrm{D}$ \\
\hline MadozGúrpide & 2015 & Spain & 33 & 61 & $\mathrm{HNC}$ & NA & $\mathrm{H}$-score $>120$ & OS & $\mathrm{D}$ \\
\hline Chau & 2011 & Canada & 49 & 56 & $\mathrm{HNC}$ & NA & $\begin{array}{l}\text { Semi-quantitative score } \\
>2\end{array}$ & OS & $\mathrm{D}$ \\
\hline Lo Muzio & 2005 & Italy & 84 & 65 & $\mathrm{HNC}$ & NA & $\begin{array}{l}\text { Stained cells accounted } \\
\text { more than } 30 \%\end{array}$ & DFS & $\mathrm{D}$ \\
\hline Cho & 2016 & South Korea & 396 & 58 & $\mathrm{HNC}$ & $\begin{array}{c}37.1 \\
(0.8-99.6)\end{array}$ & $\begin{array}{l}\text { Presence of strong and } \\
\text { diffuse nuclear and } \\
\text { cytoplasmic staining in } \\
>70 \% \text { of the HNSCC } \\
\text { cells }\end{array}$ & OS & $\mathrm{D}$ \\
\hline Kim & 2006 & South Korea & 40 & 60 & HPC & NA & $\begin{array}{l}\text { Tumor samples were } \\
\text { scored as positive of } \\
\text { they were }+ \text { or }++ \text { and } \\
\text { stained more than } 30 \% \\
\text { of the cancer cells. }\end{array}$ & OS & I \\
\hline Qian & 2002 & China & 66 & 46.4 & NPC & $79(1-163)$ & $\begin{array}{l}\text { Fluorescent intensity } \\
>94\end{array}$ & OS & I \\
\hline $\mathrm{Li}$ & 2015 & China & 376 & NA & NPC & $\begin{array}{c}62.4 \\
(2.6-97.3)\end{array}$ & $\begin{array}{l}\geq 50 \% \text { of tumor cells } \\
\text { with moderate or higher } \\
\text { staining intensity }\end{array}$ & OS/DFS & $\mathrm{D}$ \\
\hline Kim & 2011 & South Korea & 38 & 48 & NPC & $30(11-83)$ & $\begin{array}{l}\text { Stained cells accounted } \\
\text { more than } 50 \%\end{array}$ & OS & $\mathrm{D}$ \\
\hline Zhao & 2011 & China & 76 & NA & OOC & $41(4-80)$ & $\begin{array}{l}>30 \% \text { tumor cells were } \\
\text { scored }+ \text { or }++\end{array}$ & OS/DFS & I \\
\hline Perisanidis & 2013 & Austria & 113 & NA & OOC & 4.6 years & IHC score & OS/RFS & $\mathrm{D}$ \\
\hline Freudlsperger & 2010 & Germany & 211 & 58 & OOC & $42(1-172)$ & $\begin{array}{l}\text { Specimens with } \geq 50 \% \\
\text { of cancer cells }\end{array}$ & OS & I \\
\hline Aebersold & 2001 & Switzerland & 97 & 57 & OOC & 2.6 years & $\begin{array}{l}\text { Moderate }(++) \text { or strong } \\
(+++) \text { staining }\end{array}$ & OS/DFS & $\mathrm{D}$ \\
\hline Bell & 2015 & U.S.A & 200 & 52 & SGC & NA & $\begin{array}{l}\text { Strong staining in }>50 \% \\
\text { of the neoplastic cells }\end{array}$ & OS & I \\
\hline Ach & 2013 & Germany & 221 & 60.2 & SGC & $\begin{array}{l}4.85 \text { years } \\
(0.1-21.2)\end{array}$ & $\begin{array}{l}\text { Immunoreactivity score } \\
\text { (IRS) }>10\end{array}$ & DFS & I \\
\hline Endo & 2006 & Japan & 99 & 61.7 & $\mathrm{TC}$ & NA & Positive cells $\geq 45 \%$ & DFS & $\mathrm{D}$ \\
\hline Lim & 2012 & South Korea & 71 & NA & $\mathrm{TC}$ & 6.1 years & $\begin{array}{l}\text { Tumor samples were } \\
\text { scored as positive of } \\
\text { they were }+ \text { or }++ \text { and } \\
\text { stained more than } 30 \% \\
\text { of the cancer cells. }\end{array}$ & OS & I \\
\hline Kim & 2010 & South Korea & 61 & 53.5 & $\mathrm{TC}$ & NA & $\begin{array}{l}\text { Tumor samples were } \\
\text { scored as positive of } \\
\text { they were }+ \text { or }++ \text { and } \\
\text { stained more than } 30 \% \\
\text { of the cancer cells. }\end{array}$ & OS & $\mathrm{D}$ \\
\hline
\end{tabular}

Abbreviate: NA: not available; HNC: head and neck cancer; NPC: nasopharyngeal cancer; OOC: oral and oropharyngeal cancer; SGC: salivary gland cancer; TC: tongue cancer; HPC: Hypopharyngeal cancer; OS: overall survival; DFS: diseasefree survival; RFS: recurrence-free survival; D: directly extracted from the articles; I: estimated from Kaplan-Meier plots. 


\section{DISCUSSION}

c-Met was first identified in the 1980 s as an oncogene [46]. It is overexpressed in a variety of tumors and plays an important role in malignant transformation, activated c-Met could mediate tumor growth, metastasis and angiogenesis [47]. It had been reported that c-Met could activate a lots of downstream signal factors, such as MAPK, PI3K/AKT and STAT3 [48, 49]. Given its critical role in tumor malignant transformation, c-Met could be considered as a prognosis marker for cancer. But the prognosis role of c-Met in human head and neck cancer is unclear, the results is inconsistent among different studies, so we carry out this meta-analysis to combine these studies and get a more reliable result.
To our knowledge, the present meta-analysis is the first one to consider the relationships between c-Met expression and clinical pathological parameters and prognosis of human head and neck cancer. In this study, 2,417 patients from 19 studies were collected. For all kinds of head and neck cancer, the results showed that patients with higher c-Met expression had a bad overall survival rate $(P=0.002)$, but for the disease-free survival rate, the association was not significant $(P=0.055)$. Even though oral cavity and pharynx were the most common sites of the head and neck cancer, we did not find significant associations between c-Met expression and survival in oral and oropharyngeal cancer (OOC) and tongue cancer (TC), which could be the result of small sample size. So more studies with large number of patients were needed to

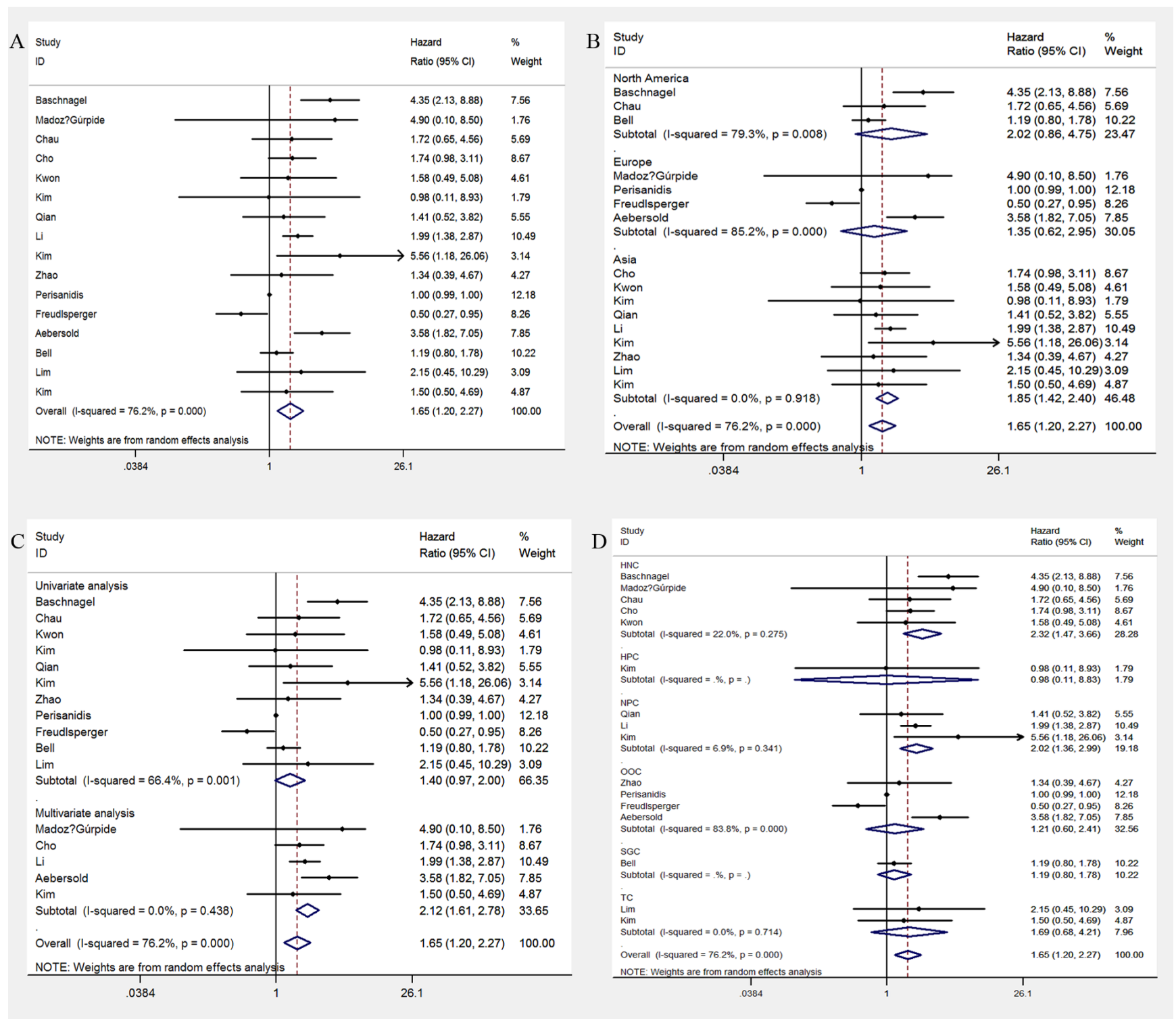

Figure 2: Forest plots of hazard ratios (HRs) for the association between c-Met expression and overall survival (OS) in head and neck cancer patients. Plots for all datasets $(\mathbf{A})$ and subgroup analysis based on region $(\mathbf{B})$, analysis type $(\mathbf{C})$ and tumor type (D). The $95 \%$ confidence intervals (CI) for individual studies are represented by a horizontal line and by a diamond for pooled effect. CI denotes confidence interval. 
Table 2: Main results of the meta-analysis

\begin{tabular}{|c|c|c|c|c|c|}
\hline Categories & Number of studies & HR & $95 \%$ CI & $\boldsymbol{P}^{*}$ & $\begin{array}{c}\text { Degree of heterogeneity } \\
\text { (II statistics; \%) }\end{array}$ \\
\hline OS & 16 & 1.65 & $1.20-2.27$ & 0.002 & $76.20 \%$ \\
\hline \multicolumn{6}{|l|}{ Region } \\
\hline Europe & 4 & 1.35 & $0.62-2.95$ & 0.451 & $85.20 \%$ \\
\hline North America & 3 & 2.02 & $0.86-4.75$ & 0.106 & $79.30 \%$ \\
\hline Asia & 9 & 1.85 & $1.42-2.40$ & $<0.001$ & $0 \%$ \\
\hline \multicolumn{6}{|l|}{ Analysis type } \\
\hline Multivariate & 5 & 2.12 & $1.61-2.78$ & $<0.001$ & $0 \%$ \\
\hline Univariate & 11 & 1.4 & $0.97-2.01$ & 0.072 & $66.40 \%$ \\
\hline \multicolumn{6}{|l|}{ Tumor types } \\
\hline $\mathrm{HNC}$ & 5 & 2.32 & $1.47-3.66$ & $<0.001$ & $22.00 \%$ \\
\hline NPC & 3 & 2.02 & $1.36-2.99$ & $<0.001$ & $6.90 \%$ \\
\hline OOC & 4 & 1.21 & $0.60-2.41$ & 0.596 & $83.80 \%$ \\
\hline $\mathrm{TC}$ & 2 & 1.69 & $0.68-4.21$ & 0.256 & $0 \%$ \\
\hline DFS & 8 & 1.48 & $0.99-2.20$ & 0.055 & $56.00 \%$ \\
\hline \multicolumn{6}{|l|}{ Region } \\
\hline Europe & 3 & 1.23 & $0.44-3.44$ & 0.7 & $84.10 \%$ \\
\hline Asia & 4 & 1.7 & $1.26-2.28$ & $<0.001$ & $0 \%$ \\
\hline \multicolumn{6}{|l|}{ Analysis type } \\
\hline Multivariate & 4 & 1.35 & $0.62-2.94$ & 0.44 & $0.00 \%$ \\
\hline Univariate & 4 & 1.59 & $1.06-2.36$ & 0.02 & $56.00 \%$ \\
\hline \multicolumn{6}{|l|}{ Tumor types } \\
\hline OOC & 2 & 1.98 & $0.86-4.55$ & 0.11 & $54.30 \%$ \\
\hline $\mathrm{HNC}$ & 3 & 1 & $0.30-3.34$ & 0.995 & $79.70 \%$ \\
\hline
\end{tabular}

Abbreviations: OS: overall survival; HNC: head and neck cancer; NPC: nasopharyngeal cancer; OOC: oral and oropharyngeal cancer; TC: tongue cancer; OS: overall survival; DFS: disease-free survival; HR: hazard ratio; CI: confidence interval. ${ }^{* *} P$ value for HR.

Table 3: Association of c-Met expression with clinical features in head and neck cancer

\begin{tabular}{cccccc}
\hline Clinical parameter & Number of studies & OR & $\mathbf{9 5 \% C I}$ & $\boldsymbol{P}^{*}$ & $\begin{array}{c}\text { Degree of heterogeneity } \\
\text { (I statistics; \%) }\end{array}$ \\
\hline Gender (male vs. female) & 9 & 1.14 & $0.89-1.49$ & 0.293 & $0 \%$ \\
T stage (T1/T2 vs. T3/T4) & 9 & 1.37 & $0.96-1.96$ & 0.08 & $34.40 \%$ \\
N stage (N0 vs. N+) & 7 & 2.11 & $1.12-3.96$ & 0.02 & $66.80 \%$ \\
Clinical stage (I/II vs. III/IV) & 7 & 1.97 & $0.86-4.51$ & 0.108 & $74.30 \%$ \\
\hline
\end{tabular}

Abbreviations: OR: odds ratio; CI: confidence interval; ${ }^{*} P$ value for OR.

clarify the relationships between c-Met expression and the survival rate of OOC and TC.

Furthermore, we found the results were different between subgroup of univariable analysis and multivariable analysis. For overall survival (OS), we found there was significant association in the subgroup of "multivariate analysis", but for disease-free survival (DFS), the results showed there was significant association in the subgroup of "univariate analysis". In survival analysis, the "univariate" was used to evaluate the relations of the single factor to the survival rate, but the single factor was seldom informative due to relations among different factors and the potential interaction among the other factors to the survival rate. These issues could be handled by multivariate analysis, which could evaluate the effect of single factor without 


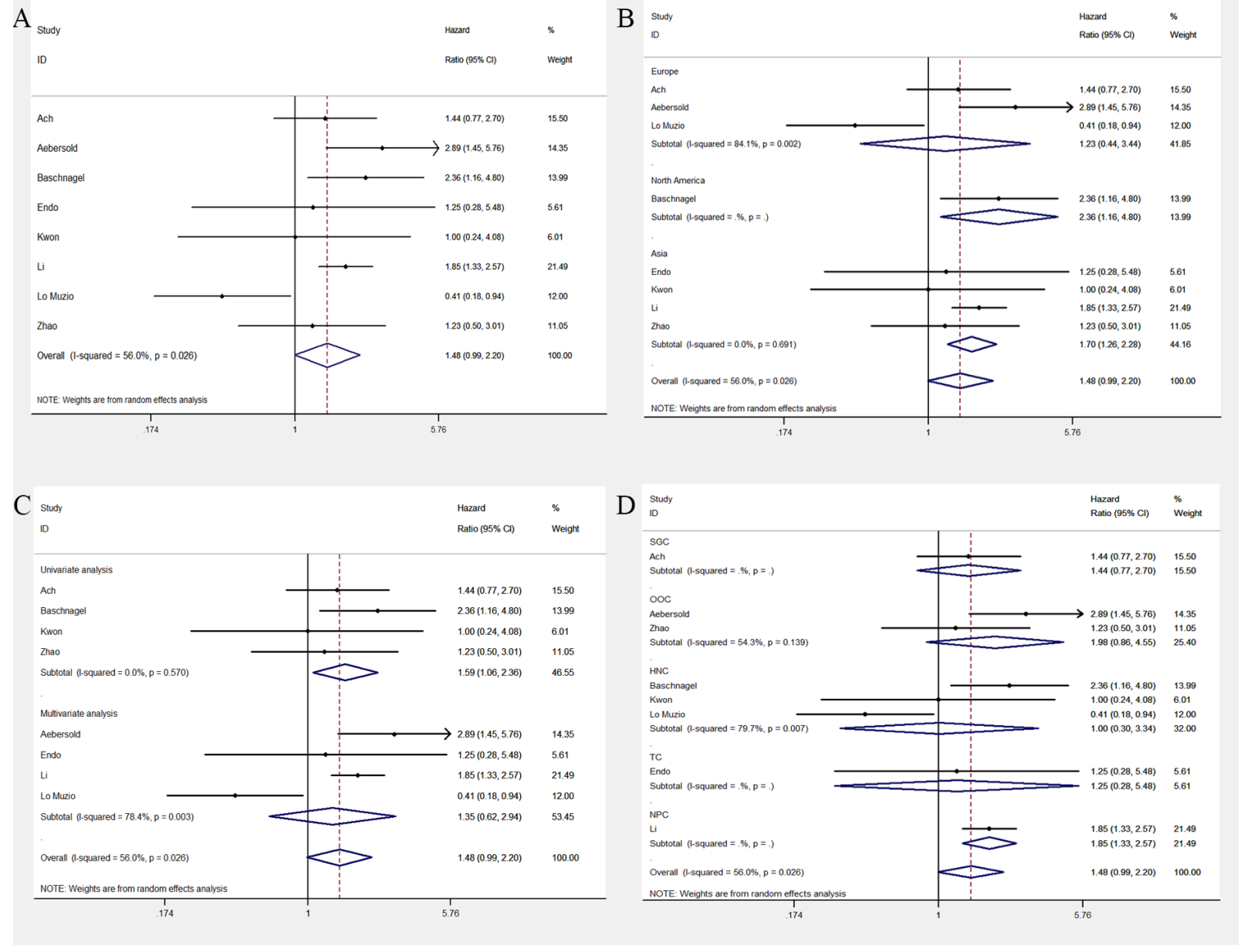

Figure 3: Forest plots of hazard ratios (HRs) for the association between c-Met expression and disease-free survival (DFS) in head and neck cancer patients. Plots for all datasets (A) and subgroup analysis based on region (B), analysis type (C) and tumor type (D). The $95 \%$ confidence intervals (CI) for individual studies are represented by a horizontal line and by a diamond for pooled effect. CI denotes confidence interval.

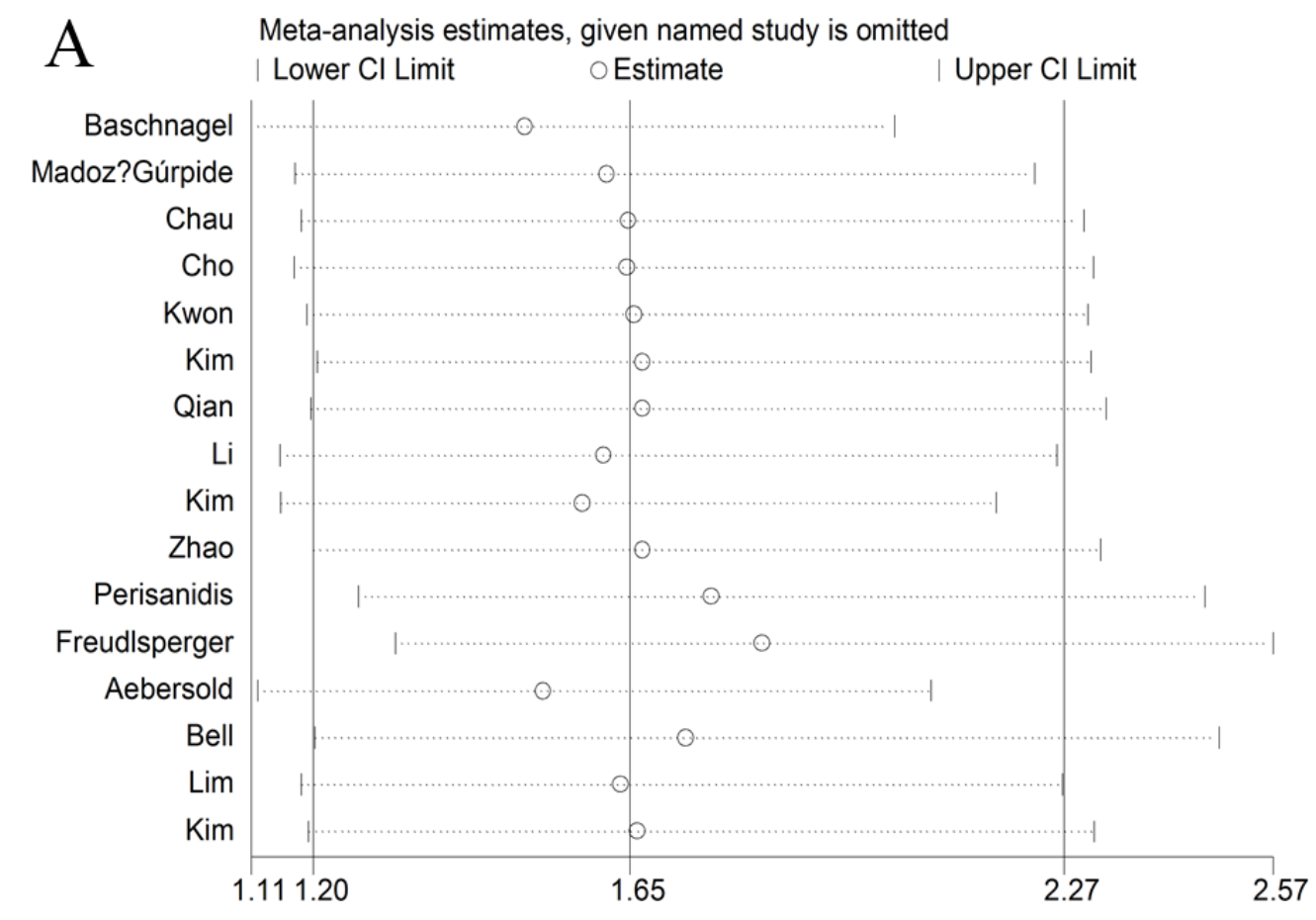


B

Meta-analysis estimates, given named study is omitted

| Lower Cl Limit

o Estimate

| Upper Cl Limit

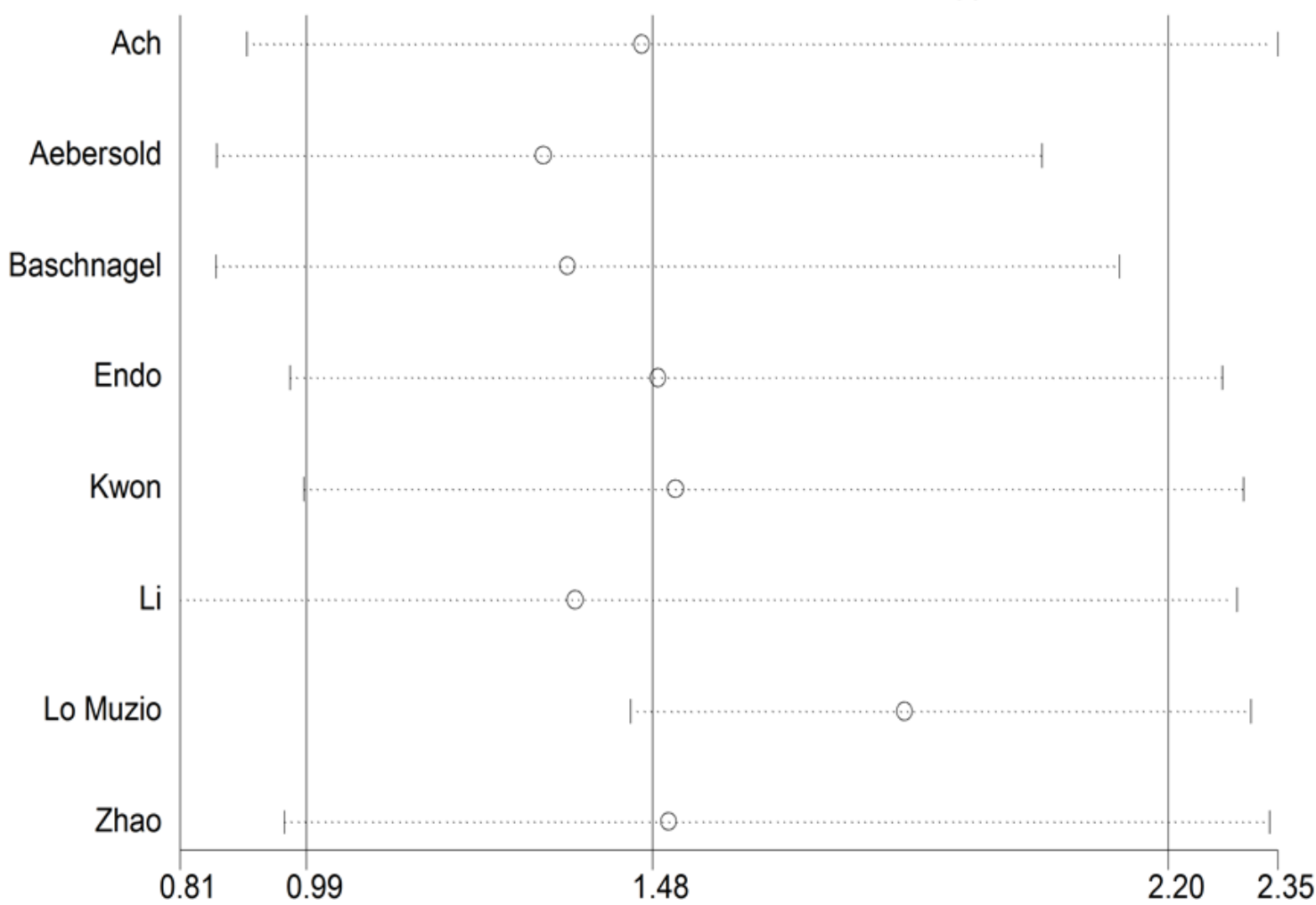

Figure 4: Sensitive analysis of the pooled hazard ratio for OS (A) and DFS (B). Meta-analysis random effects estimates were used. Results were computed by omitting each study (on the left) in turn. The two ends of every broken line represented the $95 \%$ confidence interval.

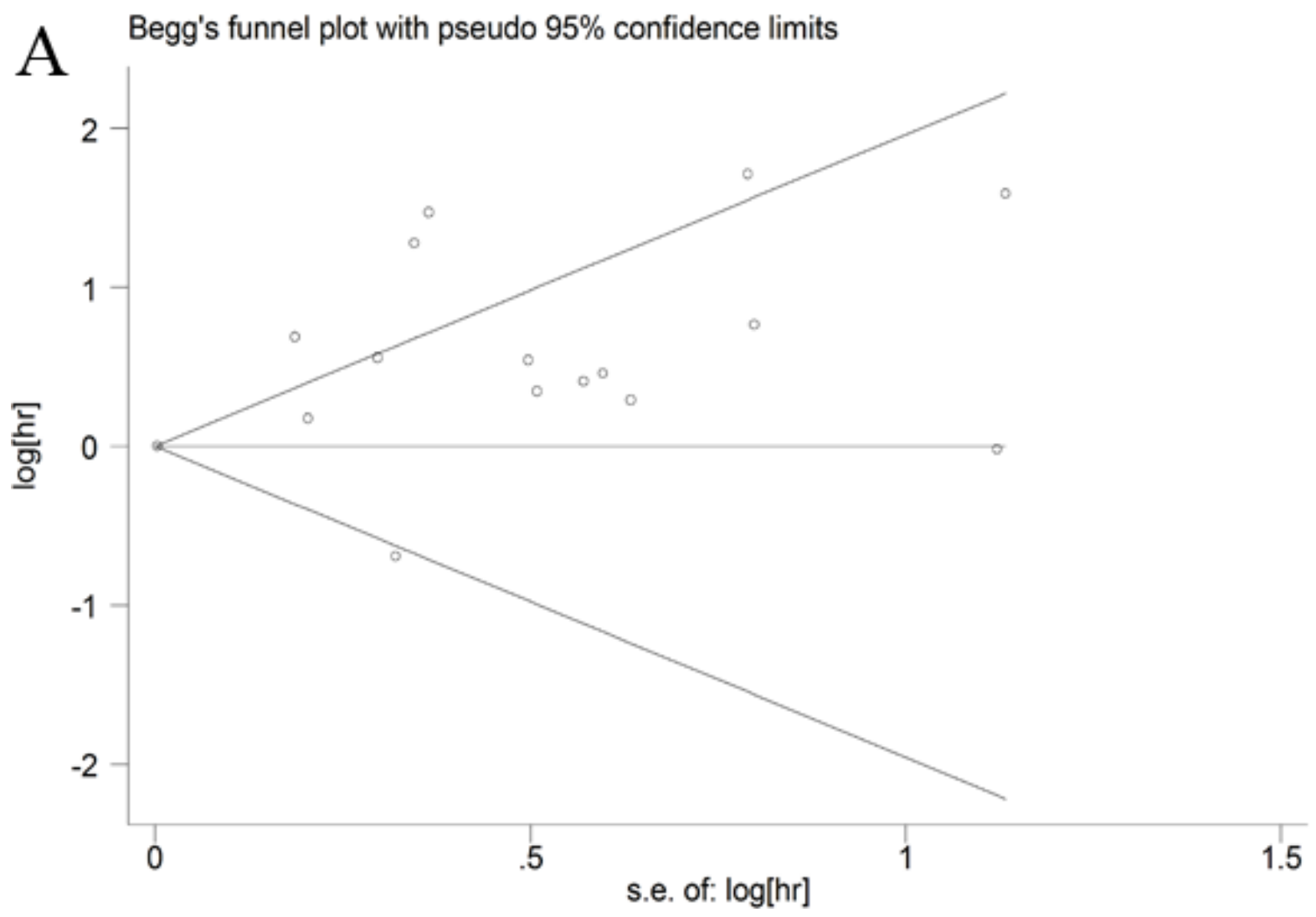




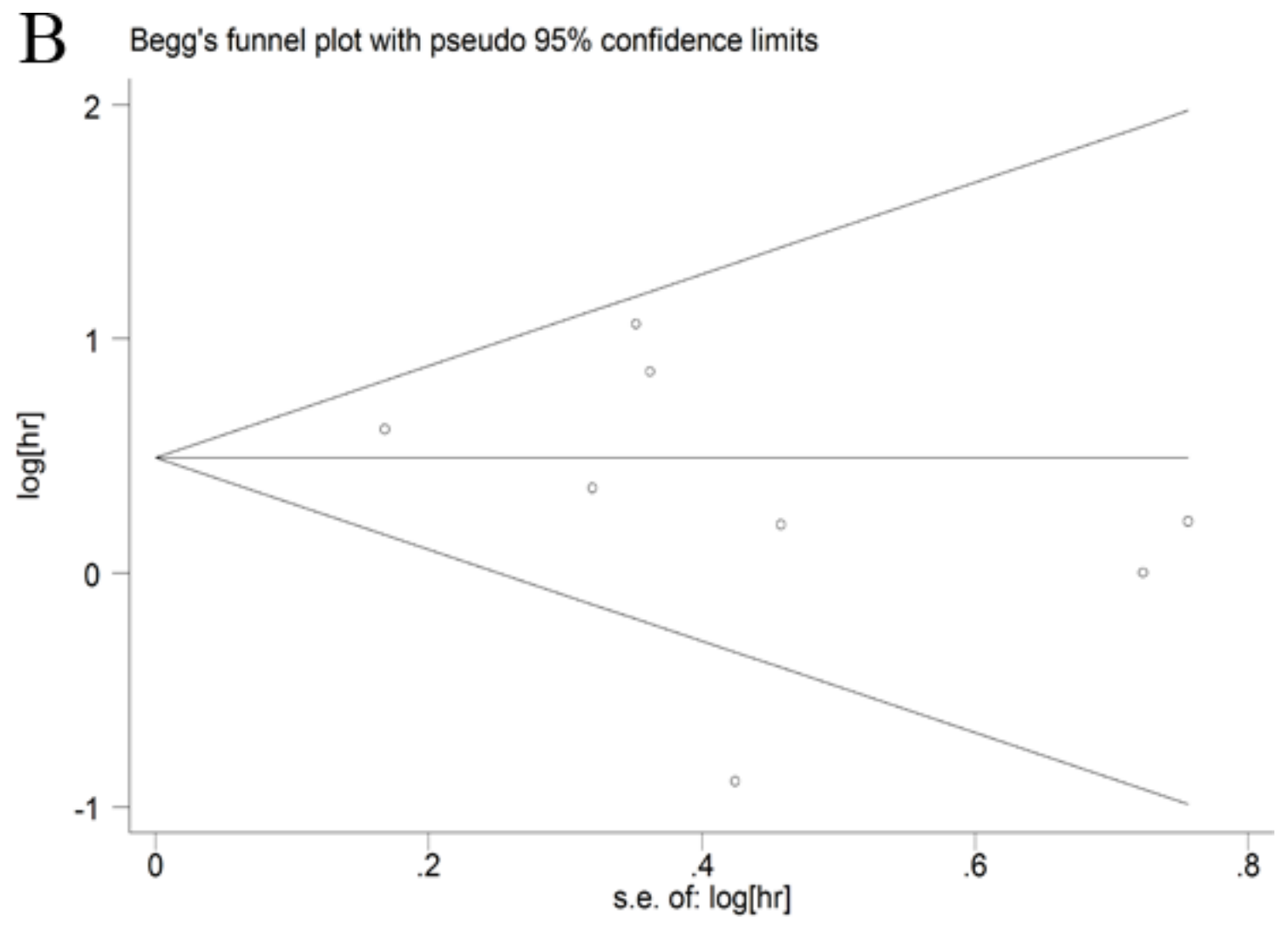

Figure 5: Funnel plot for the assessment of publication bias of the included literature for OS (A) and DFS (B).

Filled funnel plot with pseudo $95 \%$ confidence limits

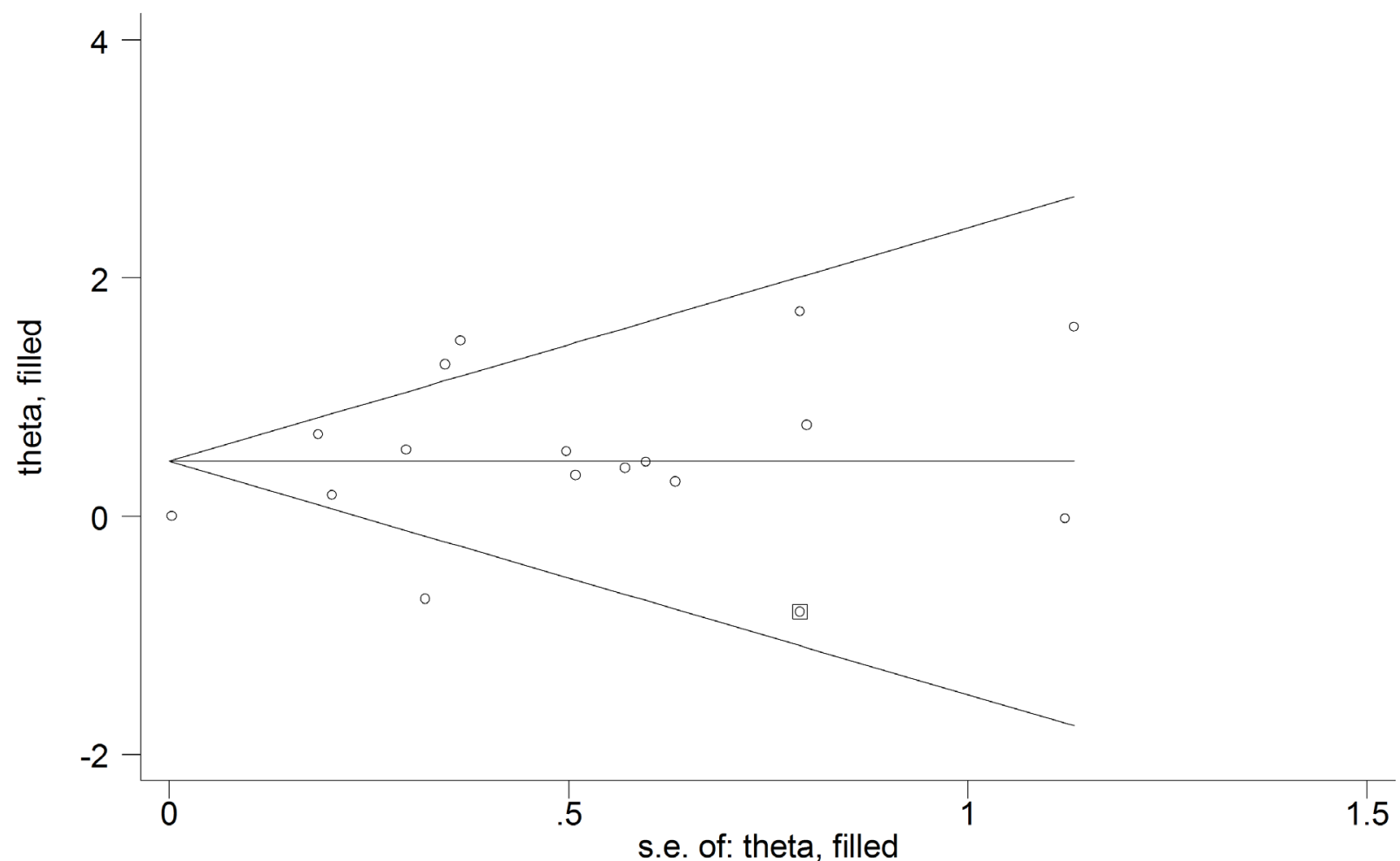

Figure 6: Funnel plot with 'filled' studies for analysis of overall survival. The circle represents the literatures enrolled in the analysis; the square represents the filled one. 
the interaction of others. So the results of multivariate analysis were much more reliable than the results of univariate analysis.

As for the relationships between c-Met expression and clinical parameters of head and neck cancer, we found the expression of c-Met was associated with the $\mathrm{N}$ stage (N0 vs. N+). Patients with higher c-Met expression had a significant higher probability to occur lymph node metastasis. Based on these results, c-Met expression could act as a valuable prognosis marker for head and neck cancer patients.

Heterogeneity is an important indication to evaluate a meta-analysis. The heterogeneity test showed that there was obvious heterogeneity among different studies. In this study, we used random-effect model to calculate the pooled OR and HR to reduce the effect of the heterogeneity to the results. As for the source of heterogeneity, it may mainly come from different tumor types, studies regions and analysis types. So, we carry out the subgroup analysis to reduce the heterogeneity. The results showed the heterogeneity reduce or disappear in most subgroups. The results showed that Asian studies were quite homogeneous, while there was obvious heterogeneity in the Europe and North American studies. The possible reason of the high heterogeneity in these subgroups was that the number of the studies in these two groups is relatively small and these studies focused on different tumor types.

Sensitivity analysis and publication bias are the other two important ways to test the liability of the results of meta-analysis. These results showed our study were accurate and trustiness. But there are still some limitations in the present study. First, the number of the enrolled studies is relatively small, especially for each kind of cancer. Second, the sample size was small, most of the included studies just had limited patients $(<100)$.

In conclusion, c-Met expression was a risk factor for head and neck cancer patients, the patients wither higher c-Met expression had a significant poorer survival rate. It would be helpful to define the high-risk patients by determination of the expression of c-Met. But more studies with larger sample size were needed to expound the relationships between c-Met expression and prognosis of head and neck cancer patients.

\section{Author contributions}

H.S., L.M. and G.L. designed the research. L.L., Z.S., X. H., X. L., and L.S. collected articles and extracted data. L.L., Z.S., L.Z., X.Z. L.Y., and J.Y. performed the statistical analysis. L.L. and H.S. wrote the manuscript. All of the authors read and approved the final manuscript.

\section{CONFLICTS OF INTEREST}

The authors declare no competing financial interests.

\section{FUNDING}

This work was supported by the grant from The First Affiliated Hospital of Harbin Medical University Foundation (No.2014B19).

\section{REFERENCES}

1. Fitzmaurice C, Allen C, Barber RM, Barregard L, Bhutta ZA, Brenner H, Dicker DJ, Chimed-Orchir O, Dandona R, Dandona L, Fleming T, Forouzanfar MH, Hancock J, et al. Global, Regional, and National Cancer Incidence, Mortality, Years of Life Lost, Years Lived With Disability, and Disability-Adjusted Life-years for 32 Cancer Groups, 1990 to 2015: A Systematic Analysis for the Global Burden of Disease Study. JAMA Oncol. 2017; 3:524-548.

2. Siegel RL, Miller KD, Jemal A. Cancer Statistics, 2017. CA Cancer J Clin. 2017; 67:7-30.

3. Peruzzi B, Bottaro DP. Targeting the c-Met signaling pathway in cancer. Clin Cancer Res. 2006; 12:3657-3660.

4. Knowles LM, Stabile LP, Egloff AM, Rothstein ME, Thomas SM, Gubish CT, Lerner EC, Seethala RR, Suzuki S, Quesnelle KM, Morgan S, Ferris RL, Grandis JR, et al. HGF and c-Met participate in paracrine tumorigenic pathways in head and neck squamous cell cancer. Clin Cancer Res. 2009; 15:3740-3750.

5. Li Y, Li W, He Q, Xu Y, Ren X, Tang X, Wen X, Yang X, Sun Y, Zeng J, Yun J, Liu N, Ma J. Prognostic value of MET protein overexpression and gene amplification in locoregionally advanced nasopharyngeal carcinoma. Oncotarget. 2015; 6:13309-13319. https://doi.org/10.18632/ oncotarget.3751.

6. Kim CH, Koh YW, Han JH, Kim JW, Lee JS, Baek SJ, Hwang HS, Choi EC. c-Met expression as an indicator of survival outcome in patients with oral tongue carcinoma. Head Neck. 2010; 32:1655-1664.

7. Lo Muzio L, Farina A, Rubini C, Coccia E, Capogreco M, Colella G, Leonardi R, Campisi G, Carinci F. Effect of c-Met expression on survival in head and neck squamous cell carcinoma. Tumor Biol. 2006; 27:115-121.

8. Tierney JF, Stewart LA, Ghersi D, Burdett S, Sydes MR. Practical methods for incorporating summary time-to-event data into meta-analysis. Trials. 2007; 8:16.

9. Begg CB, Mazumdar M. Operating characteristics of a rank correlation test for publication bias. Biometrics. 1994; 50:1088-1101.

10. DerSimonian R, Laird N. Meta-analysis in clinical trials. Control Clin Trials. 1986; 7:177-188.

11. Duval S, Tweedie R. Trim and fill: A simple funnel-plotbased method of testing and adjusting for publication bias in meta-analysis. Biometrics. 2000; 56:455-463.

12. Egger M, Davey Smith G, Schneider M, Minder C. Bias in meta-analysis detected by a simple, graphical test. BMJ. 1997; 315:629-634.

13. Chen BK, Ohtsuki Y, Furihata M, Takeuchi T, Iwata J, Liang $\mathrm{SB}$, Sonobe H. Overexpression of c-Met protein in human 
thyroid tumors correlated with lymph node metastasis and clinicopathologic stage. Pathol Res Pract. 1999; 195:427-433.

14. Lo Muzio L, Leonardi R, Mignogna MD, Pannone G, Rubini C, Pieramici T, Trevisiol L, Ferrari F, Serpico R, Testa N, De Rosa G, Staibano S. Scatter factor receptor (c-Met) as possible prognostic factor in patients with oral squamous cell carcinoma. Anticancer Res. 2004; 24:1063-1069.

15. Porte H, Triboulet JP, Kotelevets L, Carrat F, Prevot S, Nordlinger B, DiGioia Y, Wurtz A, Comoglio P, Gespach C, Chastre E. Overexpression of stromelysin-3, BM-40/SPARC, and MET genes in human esophageal carcinoma: implications for prognosis. Clin Cancer Res. 1998; 4:1375-1382.

16. De Herdt MJ, Baatenburg de Jong RJ. HGF and c-MET as potential orchestrators of invasive growth in head and neck squamous cell carcinoma. Front Biosci. 2008; 13:2516-2526.

17. Anderson MR, Harrison R, Atherfold PA, Campbell MJ, Darnton SJ, Obszynska J, Jankowski JA. Met receptor signaling: a key effector in esophageal adenocarcinoma. Clin Cancer Res. 2006; 12:5936-5943.

18. Nardone HC, Ziober AF, LiVolsi VA, Mandel SJ, Baloch ZW, Weber RS, Mick R, Ziober BL. c-Met expression in tall cell variant papillary carcinoma of the thyroid. Cancer. 2003; 98:1386-1393.

19. Chen YS, Wang JT, Chang YF, Liu BY, Wang YP, Sun A, Chiang CP. Expression of hepatocyte growth factor and c-met protein is significantly associated with the progression of oral squamous cell carcinoma in Taiwan. J Oral Pathol Med. 2004; 33:209-217.

20. Choe JY, Yun JY, Nam SJ, Kim JE. Expression of c-Met Is Different along the Location and Associated with Lymph Node Metastasis of Head and Neck Carcinoma. Korean J Pathol. 2012; 46:515-522.

21. Lee MJ, Kim N, Choung HK, Choe JY, Khwarg SI, Kim JE. Increased gene copy number of HER 2 and concordant protein overexpression found in a subset of eyelid sebaceous gland carcinoma indicate HER2 as a potential therapeutic target. J Cancer Res Clin Oncol. 2016; 142:125-133.

22. Tsukinoki K, Yasuda M, Mori Y, Asano S, Naito H, Ota Y, Osamura RY, Watanabe Y. Hepatocyte growth factor and c-Met immunoreactivity are associated with metastasis in high grade salivary gland carcinoma. Oncol Rep. 2004; 12:1017-1021.

23. Oyama T, Ichimura E, Sano T, Kashiwabara K, Fukuda T, Nakajima T. c-Met expression of thyroid tissue with special reference to papillary carcinoma. Pathol Int. 1998; 48:763-768.

24. Projetti F, Mesturoux L, Coulibaly B, Durand K, Chaunavel A, Leobon S, Gadeaud E, Caire F, Bessede JP, Labrousse F. Study of MET protein levels and MET gene copy number in 72 sinonasal intestinal-type adenocarcinomas. Head Neck. 2015; 37:1563-1568.

25. Ren Y, Cao B, Law S, Xie Y, Lee PY, Cheung L, Chen Y, Huang X, Chan HM, Zhao P, Luk J, Vande Woude G, Wong $J$. Hepatocyte growth factor promotes cancer cell migration and angiogenic factors expression: a prognostic marker of human esophageal squamous cell carcinomas. Clin Cancer Res. 2005; 11:6190-6197.

26. Wang H, Jiang D, Song Q, Xu C, Shi Y, Li X, Huang J, Xu Y, Sujie A, Zeng H, Zhong Y, Tan L, Hou Y. Prognostic impact and potential interaction of EGFR and c-Met in the progression of esophageal squamous cell carcinoma. Tumour Biol. 2016; 37:9771-9779.

27. Zhao Y, Zhang J, Tian Y, Xue C, Hu Z, Zhang L. Met tyrosine kinase inhibitor, PF-2341066, suppresses growth and invasion of nasopharyngeal carcinoma. Drug Des Devel Ther. 2015; 9:4897-4907.

28. Baschnagel AM, Tonlaar N, Eskandari M, Kumar T, Williams L, Hanna A, Pruetz BL, Wilson GD. Combined CD44, c-MET, and EGFR expression in p16-positive and p16-negative head and neck squamous cell carcinomas. J Oral Pathol Med. 2017; 46:208-213.

29. Endo K, Shirai A, Furukawa M, Yoshizaki T. Prognostic value of cell motility activation factors in patients with tongue squamous cell carcinoma. Hum Pathol. 2006; 37:1111-1116.

30. Zhao D, Wang SH, Feng Y, Hua CG, Zhao J, Tang XF. Intratumoral c-Met expression is associated with vascular endothelial growth factor $\mathrm{C}$ expression, lymphangiogenesis, and lymph node metastasis in oral squamous cell carcinoma: implications for use as a prognostic marker. Hum Pathol. 2011; 42:1514-1523.

31. Kwon MJ, Kim DH, Park HR, Shin HS, Kwon JH, Lee DJ, Kim JH, Cho SJ, Nam ES. Frequent hepatocyte growth factor overexpression and low frequency of c-Met gene amplification in human papillomavirus-negative tonsillar squamous cell carcinoma and their prognostic significances. Hum Pathol. 2014; 45:1327-1338.

32. Perisanidis C, Wrba F, Brandstetter A, Kornek G, Mitchell D, Seemann R, Selzer E, Ewers R, Filipits M. Impact of epidermal growth factor receptor, mesenchymalepithelial transition factor, and insulin-like growth factor receptor 1 expression on survival of patients with oral and oropharyngeal cancer. Br J Oral Maxillofac Surg. 2013; 51:234-240.

33. Baschnagel AM, Williams L, Hanna A, Chen PY, Krauss DJ, Pruetz BL, Akervall J, Wilson GD. c-Met expression is a marker of poor prognosis in patients with locally advanced head and neck squamous cell carcinoma treated with chemoradiation. Int J Radiat Oncol Biol Phys. 2014; 88:701-707.

34. Lim YC, Han JH, Kang HJ, Kim YS, Lee BH, Choi EC, Kim $\mathrm{CH}$. Overexpression of c-Met promotes invasion and metastasis of small oral tongue carcinoma. Oral Oncol. 2012; 48:1114-1119.

35. Qian CN, Guo X, Cao B, Kort EJ, Lee CC, Chen J, Wang LM, Mai WY, Min HQ, Hong MH, Vande Woude GF, Resau JH, Teh BT. Met protein expression level correlates with survival in patients with late-stage nasopharyngeal carcinoma. Cancer Res. 2002; 62:589-596. 
36. Madoz-Gurpide J, Zazo S, Chamizo C, Casado V, Carames C, Gavin E, Cristobal I, Garcia-Foncillas J, Rojo F. Activation of MET pathway predicts poor outcome to cetuximab in patients with recurrent or metastatic head and neck cancer. J Transl Med. 2015; 13:282.

37. Mok TS, Hsia TC, Tsai CM, Tsang K, Chang GC, Chang JW, Sirisinha T, Sriuranpong V, Thongprasert S, Chua DT, Moore N, Manegold C. Analysis and significance of c-MET expression in adenoid cystic carcinoma of the salivary gland. Cancer Biol Ther. 2015; 16:834-838.

38. Ach T, Zeitler K, Schwarz-Furlan S, Baader K, Agaimy A, Rohrmeier C, Zenk J, Gosau M, Reichert TE, Brockhoff G, Ettl T. Aberrations of MET are associated with copy number gain of EGFR and loss of PTEN and predict poor outcome in patients with salivary gland cancer. Virchows Arch. 2013; 462:65-72.

39. Chau NG, Perez-Ordonez B, Zhang K, Pham NA, Ho J, Zhang T, Ludkovski O, Wang L, Chen EX, Tsao MS, Kamel-Reid S, Siu LL. The association between EGFR variant III, HPV, p16, c-MET, EGFR gene copy number and response to EGFR inhibitors in patients with recurrent or metastatic squamous cell carcinoma of the head and neck. Head Neck Oncol. 2011; 3:11.

40. Freudlsperger C, Alexander D, Reinert S, Hoffmann J. Prognostic value of c-Met expression in oral squamous cell carcinoma. Exp Ther Med. 2010; 1:69-72.

41. Kim CH, Moon SK, Bae JH, Lee JH, Han JH, Kim K, Choi EC. Expression of hepatocyte growth factor and c-Met in hypopharyngeal squamous cell carcinoma. Acta Otolaryngol. 2006; 126:88-94.

42. Kim YJ, Go H, Wu HG, Jeon YK, Park SW, Lee SH. Immunohistochemical study identifying prognostic biomolecular markers in nasopharyngeal carcinoma treated by radiotherapy. Head Neck. 2011; 33:1458-1466.

43. Cho YA, Kim EK, Heo SJ, Cho BC, Kim HR, Chung JM, Yoon SO. Alteration status and prognostic value of MET in head and neck squamous cell carcinoma. J Cancer. 2016; 7:2197-2206.

44. Aebersold DM, Kollar A, Beer KT, Laissue J, Greiner RH, Djonov V. Involvement of the hepatocyte growth factor/ scatter factor receptor c-met and of Bcl-xL in the resistance of oropharyngeal cancer to ionizing radiation. Int J Cancer. 2001; 96:41-54.

45. Brusevold IJ, Soland TM, Khuu C, Christoffersen T, Bryne M. Nuclear and cytoplasmic expression of Met in oral squamous cell carcinoma and in an organotypic oral cancer model. Eur J Oral Sci. 2010; 118:342-349.

46. Cooper CS, Park M, Blair DG, Tainsky MA, Huebner K, Croce CM, Vande Woude GF. Molecular cloning of a new transforming gene from a chemically transformed human cell line. Nature. 1984; 311:29-33.

47. Birchmeier C, Birchmeier W, Gherardi E, Vande Woude GF. Met, metastasis, motility and more. Nat Rev Mol Cell Biol. 2003; 4:915-925.

48. Molina JR, Adjei AA. The Ras/Raf/MAPK pathway. J Thorac Oncol. 2006; 1:7-9.

49. Lee KH, Choi EY, Hyun MS, Jang BI, Kim TN, Kim SW, Song SK, Kim JH, Kim JR. Association of extracellular cleavage of E-cadherin mediated by MMP-7 with HGFinduced in vitro invasion in human stomach cancer cells. Eur Surg Res. 2007; 39:208-215. 